\title{
Determination of Polychlorinated Dibenzo Dioxin Levels in Fresh Milk from the Dairy Factories of Southwest Iran
}

\author{
Mohsen Rezaei ${ }^{1,2 *}$, Zahra Nazari Khorasgani ${ }^{1}$, Azadeh Nakisa ${ }^{1}$, Nima Imani ${ }^{1}$, Saeid Rezaee ${ }^{3}$, Mohammad Javad Khodayar ${ }^{1}$ and Heibatullah \\ Kalantari ${ }^{1}$
}

${ }^{1}$ Department of Toxicology and Pharmacology, Pharmacy School, Jundishapur University of Medical Sciences, Ahvaz, Iran

${ }^{2}$ Department of Toxicology, Faculty of Medical Sciences, Tarbiat Modares University, Tehran, Iran

${ }^{3}$ Departments of Pharmaceutics, Pharmacy School, University of Medical Sciences, Zanjan, Iran

\begin{abstract}
Background: Currently, release of highly toxic polychlorinated dibenzo-p-dioxins (PCDDs) from combustion processes and industrial activities in the environment, their persistence and bioaccumulation in human attracted more attention and dairy products are among the most important sources of human exposure. This study was aimed to determine the most toxic congeners of dioxins in fresh cow's milk samples collected from the Southwest of Iran.

Materials and Methods: 15 composite samples of pasteurized milk from the each of 3 major dairy factories of Khuzestan Province in spring, summer and autumn from July 2011 to March 2012 (3 seasons) were collected. After precipitation of the proteins, fat phase was reduced and extracted with hexane and ether. After dehydration, furans existed in fat percolated with hexane through a column chromatography which contained silica gel/silver nitrate, silica gel, silica gel/sulfuric acid respectively and with percolating output through another column contained activated charcoal and silica gel and washing the lower column with a mixture of dichloromethane-hexane and toluene, concentrated and dissolved in mobile phase and analyzed using HPLC: $150 \mathrm{~mm} \times 4.6 \mathrm{~mm}$ ID, $5 \mu \mathrm{m}$ cosmosil 5 NPE column equipped with a UV detector at 254 and $267 \mathrm{~nm}$, mobile phase:methanol/water $(80: 20, \mathrm{v} / \mathrm{v})$ at flow rate of $1 \mathrm{ml} / \mathrm{min}$.

Results: All samples were found to be contaminated with dioxins comparatively. The concentration of $2,3,7,8$ TCDD and 1, 2, 3, 7, 8 PCDD in lipid content (2-3\%) were detected in the range of 0.96-3.17 TEQ pg/g and 0.59-2.87 TEQ pg/g respectively. The mean concentrations of dioxins during summer were higher for all factories than other seasons and the lowest content were obtained during winter.
\end{abstract}

Keywords: Polychlorinated dibenzo-p-dioxins; Milk; HPLC

\section{Introduction}

Milk and dairy products are significant parts of a healthy diet that play important role in our daily life. Unfortunately, a lot of data about chemical contamination of milk including dioxins and furans have been reported [1]. Polychlorinated dibenzo-p-dioxins (PCDDs) are a class of environmental pollutants that produced during uncontrolled combustion process in the presence of chlorine, such as wild fire or during production of some pesticides [2]. Among this family 2,3,7,8 TCDD and 1, 2,3,7,8 PCDD are the most toxic dioxins which by many available data their toxicity was strongly demonstrated [3,4]. They are associated with various pathogeneses such as hormonal disorders and immune system dysfunction [5]. Chemical body burden reports that dioxin exposure has been linked to diabetes, increased infections, thyroid diseases, lung and dental problems and many more diseases.

Dioxins are classified as human carcinogenic pollutants by international agency for research on cancer (IARC) in 1977 [6]. The main source of human exposure to dioxins is through food intake (>90\%) [7]. Due to the slow kinetics and high lipophilic properties of these chemicals, they can accumulate in fatty tissue.

Among the foodstuffs, milk and dairy products are important parts for a healthy diet [8]. To our knowledge, there was no data about the occurrence of dioxins in milk from Southwest of Iran even though due to geographical and industrial conditions, it has raised many concerns about the presence of pollutants in that area; consequently, this study was designed to analyze two dioxins in milk samples of Khuzestan province in Iran. For determining the levels of furans, various methods have been used such as gas chromatography with the mass spectroscopy (GC-Ms), high resolution gas chromatography with high resolution mass spectroscopy (HRGC-HRMS), high resolution gas chromatography with electron capture detector (HRGC-ECD), chemically activated luciferase gene expression (CALUX) bioassay, high performance liquid chromatography with the mass spectroscopy (HPLC-Ms) and HPLC with the UV detector [9-12]. Among these methods, HPLC with the UV detector due to its relatively lower cost and device accessibility was selected for this study.

\section{Materials and Methods}

Sampling: In this research sample sizes was determined by G*Power software (version 3.1). 45 samples each comprising of 15 packs of pasteurized milk was collected from 3 factories; Jamus Khoramshahr, Torent Behbahan and Pegah Khuzestan during the period of July 2011 to March 2012 in 3 seasons: summer, autumn and winter. Samples were transferred to toxicology lab and stored frozen $\left(<-18^{\circ} \mathrm{C}\right)$ until analysis.

Reagents: 2,3,7,8 TCDD and 1, 2, 3, 7, 8 PCDD standard solutions were purchased from Cambridge Isotope Company (USA) at the

*Corresponding author: Mohsen Rezaei, Department of Toxicology and Pharmacology, Pharmacy School, Jundishapur University of Medical Sciences, Ahvaz, Iran, Tel: 09304969010; E-mail: rezaei.mohsen@gmail.com

Received May 11, 2015; Accepted June 06, 2015; Published June 10, 2015

Citation: Rezaei M, Khorasgani ZN, Nakisa A, Imani N, Rezaee S, et al. (2015) Determination of Polychlorinated Dibenzo Dioxin Levels in Fresh Milk from the Dairy Factories of Southwest Iran. J Environ Anal Toxicol 5: 301. doi:10.4172/21610525.1000301

Copyright: @ 2015 Rezaei M, et al. This is an open-access article distributed under the terms of the Creative Commons Attribution License, which permits unrestricted use, distribution, and reproduction in any medium, provided the original author and source are credited. 
Citation: Rezaei M, Khorasgani ZN, Nakisa A, Imani N, Rezaee S, et al. (2015) Determination of Polychlorinated Dibenzo Dioxin Levels in Fresh Milk from the Dairy Factories of Southwest Iran. J Environ Anal Toxicol 5: 301. doi:10.4172/2161-0525.1000301

Page 2 of 5

concentration of $50 \mathrm{ppm}$ in $\mathrm{n}$-Nonane $(0.5 \mathrm{ml}$ of each). Methanol for HPLC, acetonitrile, toluene, hexane, diethyleter, potassium oxalate, sulfuric acid, silver nitrate, sodium chloride and silica gel 50G were taken from Merck Company (Germany).

Standard preparation: Stock standard solution of mix 2,3,7,8 TCDD and 1, 2, 3, 7, 8 PCDD prepared at concentration of $1 \mathrm{ppm}$ in methanol-water (80-20\%). All the working mix dioxin solutions were prepared by diluting stock standard solution with methanol-water $(80$ $20 \%$ ) at the concentrations of $0.75,1 / 25,2 / 5,5,10 \mathrm{ppb}$.

HPLC: HPLC method were performed using 10 ADvp HPLC system (Shimadzu, Japan) with Shimadzu LC-10 ADvp pump, shimadzu UV VIS-detector SPD-10A, set at dual wavelengths and the NPE column $(5 \mu \mathrm{m}, 4.6 \mathrm{~mm}$ I.D. $\times 150 \mathrm{~mm})$ packed with particles of Nitrophenylethyl group bonded. Isocratic state set at flow rate of $1 \mathrm{ml} /$ min and methanol-water (80-20\%) used as a mobile phase.

Extraction procedure: A liquid-liquid extraction method was used in this study based on the method used by Kawashiro et al. in 2008 [13]. $10 \mathrm{ml}$ ethanol, $0.4 \mathrm{ml}$ potassium oxalate $25 \%$ and $5 \mathrm{ml}$ diethyl ether were added to $10 \mathrm{ml}$ of each sample. Then liquid-liquid extraction was done by adding $6 \mathrm{ml}$ hexane in a decanter. $\mathrm{n}$-hexane extraction was repeated 3 times. Organic layer consisting of dioxins was separated and washed by $25 \mathrm{ml}$ of $5 \%, 10 \%, 20 \%$ sodium chloride and $10 \mathrm{ml}$ of sodium sulfate respectively. Residue was evaporated, dried and weighted for cleanup.

Cleanup: Two connected chromatographic columns were used for cleanup (10 cm height, $0.5 \mathrm{ml}$ ID). Upper column was filled with $2 \mathrm{~g}$ anhydrous sodium sulfate, $1 \mathrm{~g}$ silver nitrate silica gel (10\%), $0.5 \mathrm{~g}$ silica gel, $0.5 \mathrm{~g}$ sulfuric acid silica gel (44\%), $2 \mathrm{~g}$ anhydrous sodium sulfate and lower column was filled with $1 \mathrm{~g}$ anhydrous sodium sulfate, $0.5 \mathrm{~g}$ activated carbon silica gel, $1 \mathrm{~g}$ anhydrous sodium sulphate respectively. The concentrated extract was dissolved in $1 \mathrm{ml} n$-hexane then percolated with $50 \mathrm{ml} \mathrm{n}$-hexane in columns. Dioxins were collected by passing $50 \mathrm{ml}$ dichloromethane-hexane $(25 \%)$ and $130 \mathrm{ml}$ toluene respectively through lower column then concentrated and eluted in 1 $\mathrm{ml}$ of methanol-water $(80-20 \%)$.

\section{Determination of dioxins}

HPLC method: The injection volume of standard solutions and samples was $20 \mu \mathrm{l}$ and the column temperature was set at $30^{\circ} \mathrm{C}$. Emission and excitation wavelengths were $254 \mathrm{~nm}$ (for 2,3,7,8 TCDD) and $267 \mathrm{~nm}$ (for 1, 2, 3, 7, 8 PCDD) $\mathrm{nm}$. HPLC identification of 2,3,7,8 TCDD and 1, 2, 3, 7, 8 PCDD were done by comparing retention times in chromatograms of standard solutions (Figures 1 and 2) and samples solutions (Figures 3 and 4). Linearity of standard curves was studied in the range of $0.75-10 \mathrm{ppb}(0.75,1.25,2.5,5,10 \mathrm{ppb})$. Retention times for 2, 3, 7, 8 TCDD and 1, 2, 3, 7, 8 PCDD under this condition were $5.922 \pm 0.004$ and 6.3110 .004 respectively. Dioxin concentration were determined by using linear equations from calibration curves $(2,3$, 7, 8 TCDD: $15,254.76956 \mathrm{X}-2,339.95128, \mathrm{R}^{2}=0.99990$ and $1,2,3,7,8$ PCDD: $\left.14,183.23275 \mathrm{X}+204.05688, \mathrm{R}^{2}=0.99990\right)$.

Limit of detection (LOD) and limit of quantitation (LOQ) were determined for both of dioxins and were 0.2 and $0.3 \mathrm{ppb}$ respectively. Accuracy of method identified by means of absolute recoveries. For recovery experiments, four different concentrations of standard solutions; $0.75,1.25,2$ and $5 \mathrm{ppb}(1 \mathrm{ml}$ of each) were spiked to milk sample. Then for each concentration, extraction was done and dioxin level in sample was determined (five times for each standard solution). Then average of three measurements was calculated. Evaluated data were in range $80-85 \%$ that proving efficient extraction procedure and acceptable accuracy (Table 1).

Precision and repeatability was estimated by evaluating inter-day and intra-day's ( $\mathrm{n}=6$ for all concentration of working standards). Interday RSD\% for 2, 3, 7, 8 TCDD and 1, 2, 3, 7, 8 PCDD were in range of 2.88-7.71 and 2.45-7.46 and intra-day RSD\% for 2,3,7,8 TCDD and $1,2,3,7,8$ PCDD were in range of 4.56-7.19 and 2.67-7.65 respectively (Tables 2 and 3).These results showed that the precision of method is acceptable.

\section{Statistical Analysis}

For statistical analysis SPSS software and general linear model (GLM) was used (SPSS Inc. Chicago, USA).

\section{Results}

2, 3, 7, 8 TCDD and 1, 2, 3, 7, 8 PCDD content of the pasteurized milk samples were shown in (Table 4). Results showed that 2, 3, 7, 8 TCDD and 1, 2, 3, 7, 8 PCDD were present in all samples. Statistical analysis showed that the concentration of dioxins in summer was more than other seasons and dioxin contamination of samples during winter was less than other seasons (Figure 5).

These results also indicated that there were no significant differences between the concentrations of dioxins in the same seasons. The levels of 2, 3, 7, 8 TCDD and 1, 2, 3, 7, 8 PCDD were in range of 0.96-3.17 $\mathrm{pg} / \mathrm{g}$ fat and $0.59-2.87 \mathrm{pg} / \mathrm{g}$ fat respectively.

The maximum concentration of 2, 3, 7, 8 TCDD and 1, 2, 3, 7, $8 \mathrm{PCDD}$ was $3.17 \mathrm{pg} / \mathrm{g}$ fat and $2.87 \mathrm{pg} / \mathrm{g}$ fat respectively, observed

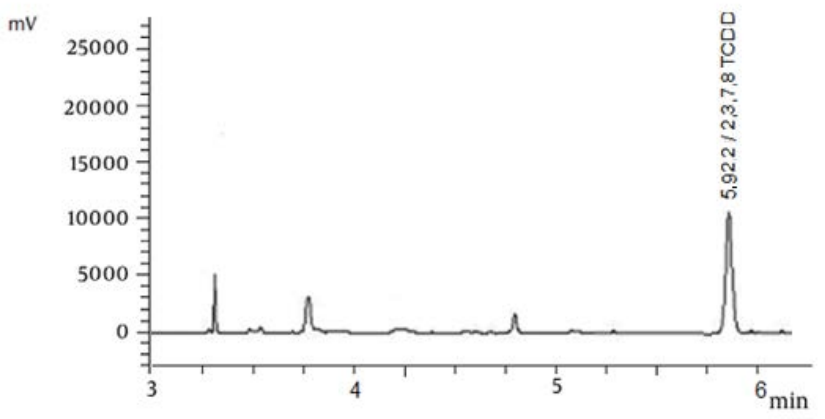

Figure 1: HPLC chromatogram of $5 \mathrm{ng} / \mathrm{ml}$ working standard solution of 2,3,7,8 TCDD and 1, 2, 3, 7, 8 PCDD, $254 \mathrm{~nm}$ wavelength, NPE column.

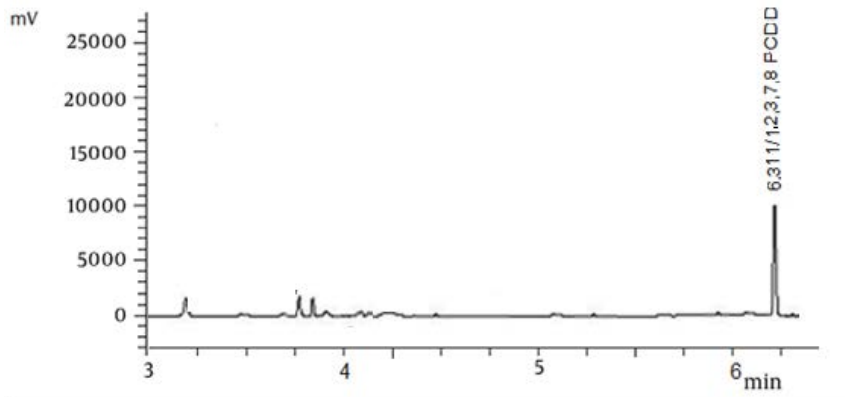

Figure 2: HPLC chromatogram of $5 \mathrm{ng} / \mathrm{ml}$ working standard solution of 2,3,7,8 TCDD and 1, 2, 3, 7, 8 PCDD, $267 \mathrm{~nm}$ wavelength, NPE column. 


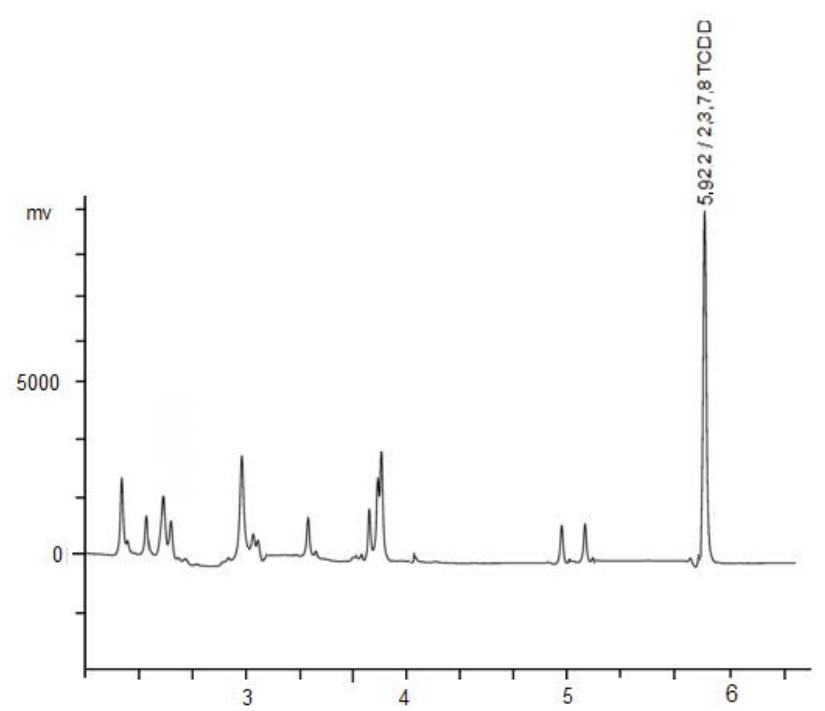

Figure 3: HPLC chromatogram of milk sample containing 2, 3, 7, 8 TCDD, $254 \mathrm{~nm}$ wavelength, NPE column.

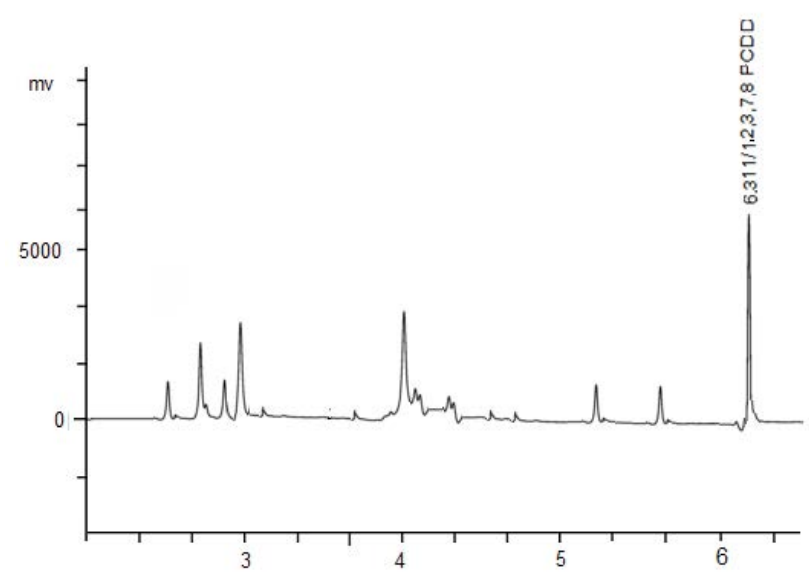

Figure 4: HPLC chromatogram of milk sample containing $1,2,3,7,8$ PCDD, $267 \mathrm{~nm}$ wavelength, NPE column.

in samples of Pegah Khuzestan factory in summer and the lowest concentration of 2, 3, 7, 8 TCDD and 1, 2, 3, 7, 8 PCDD was 0.96 $\mathrm{pg} / \mathrm{g}$ fat And $0.59 \mathrm{pg} / \mathrm{g}$ fat respectively, detected in samples of Jamus Khoramshahr factory in winter.

The total concentration of 2, 3, 7, 8 TCDD and 1, 2, 3, 7, 8 PCDD were $2.25 \mathrm{pg}$ TEQ/g fat and $1.77 \mathrm{pg}$ TEQ/g fat respectively. The average TEQs concentration of dioxins in summer and autumn was $5.84 \mathrm{pg}$ TEQ/g fat and $4.48 \mathrm{pg}$ TEQ/g fat respectively. The mean total TEQs level of dioxins in milk sample was 4.02 pg PCDD-TEQs /g.

\section{Discussion}

Due to high distribution, persistence and severe toxicities, occurrence of dioxins was extensively investigated in foodstuffs and environment. In 1994 Vartiainen and Hallikainen studied the levels of PCDD/Fs in Finnish foods, cow milk samples from the largest dairies, egg samples from the major producers and meat from the main slaughterhouses in Finland. For twenty milk samples, the mean total level of PCDD/F was 38 pg TEO/g (range 18-78 pg TEQ/g) [14].
Based on their results the average TEQs concentration of PCDD/Fs was more than the mean total TEQs of two dioxins in our research (4.02 pg PCDD-TEQs/g). Also, In 1999 Ramos et al. determined Levels of PCBs, PCDDs and PCDFs in commercial butter samples in Spain. The average concentration of PCDDs and PCDFs in 21 butter samples was 0.41 and $0.70 \mathrm{pg}$ TEQs/g fat, respectively [15]. Again, the total average concentration of two dioxins in our research (4.02 pg PCDD-TEQs /g) was more than the mean concentration of PCDDs in this study.

In 2002 Focant $e$ t al. determined the concentration of 7 PCDDs, 10 PCDFs and 4 non-ortho (coplanar) polychlorinated biphenyls (PCBs) in 197 foodstuffs samples of animal origin including milk from Belgium during 2000 to 2001. The results showed that the mean concentration of $2,3,7,8$-TCDD in milk was $1.1 \mathrm{pg} / \mathrm{g}$ of fat [16]. In our study the total average concentration of $2,3,7,8 \mathrm{TCDD}$ was $2.25 \mathrm{pg}$ TEQ/g fat that is far more from those results.

In 2008 Benoit Durand et al. determined the concentrations of PCDD/Fs and dioxin-like PCBs (DL-PCBs) in raw cow's milk. A random sampling scheme categorized by region was applied to collect 239 raw milk samples from 17 dairy companies in France. The results showed that the average concentration of PCDD/Fs was $0.33 \mathrm{pg}$ TEQs/g fat [17]. Comparison of data from our study with their results indicated that the average TEQs concentrations of two PCDDs in our study $(4.02$ pg PCDD-TEQs /g) are higher. Also, obtained levels from our study were higher than what was reported by Lizak et al. [18]. They studied the occurrence of PCDD/Fs in raw cow's and goat's milk from some of polish farms. The samples were taken from farmers in the period of 2006 to 2009. The average concentration of dioxins and furans in cow's milk was 0.88 and $1.46 \mathrm{pg}$ WHO-TEQ/g fat in goat's milk [18].

Our data showed that the concentrations of dioxins in summer were more than other seasons and interestingly dioxin contamination of samples during winter was less than other seasons. Higher incidence of dust storm and dust particles, additional soil contamination due to agricultural activities and use of fertilizers, further air pollution due to reduced rainfall at summer and the use of livestock from contaminated sources may explain why the summer values were more than other seasons. Considering the extremely toxic effects of dioxins on human health comprising of the destruction of immune system, disruption of hormonal and genetic states and increased risk of cancer, continuous monitoring of foodstuff seems to be necessary worldwide. Moreover, modification of standards and regulations over time for different industrial and food manufacturing areas need more attention. The

\section{- Mean concentration of 2,3,7,8 TCDD \\ Mean concentration of 1,2,3,7,8 PCDD}

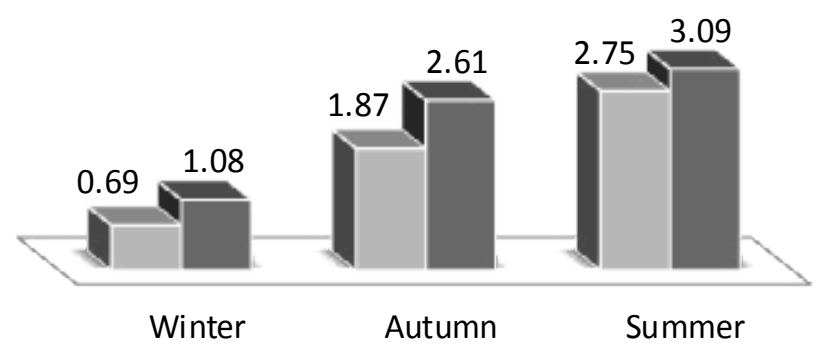

Figure 5: Total mean concentration (pg/g fat) of 2, 3, 7, 8 TCDD and 1, 2, $3,7,8$ PCDD in the samples of 3 factories in 3 seasons. 
Citation: Rezaei M, Khorasgani ZN, Nakisa A, Imani N, Rezaee S, et al. (2015) Determination of Polychlorinated Dibenzo Dioxin Levels in Fresh Milk from the Dairy Factories of Southwest Iran. J Environ Anal Toxicol 5: 301. doi:10.4172/2161-0525.1000301

Page 4 of 5

\begin{tabular}{|c|c|c|c|c|c|c|}
\hline \multirow{2}{*}{ Sample Type } & \multicolumn{2}{|c|}{ Equivalent concentration added (ppb) } & \multicolumn{2}{|c|}{ Measurable concentration (ppb) } & \multicolumn{2}{|c|}{ Mean Recovery $(\%+S D)$} \\
\hline & $2,3,7,8 \mathrm{TCDD}$ & 1,2,3,7,8 PCDD & $2,3,7,8 \mathrm{TCDD}$ & 1,2,3,7,8 PCDD & $2,3,7,8 \mathrm{TCDD}$ & $1,2,3,7,8$ PCDD \\
\hline \multirow{4}{*}{ Milk } & 0.75 & 0.75 & 0.60 & 0.60 & $80 \pm 0.14$ & $80 \pm 0.14$ \\
\hline & 1.25 & 1.25 & 1.02 & 1.02 & $82 \pm 0.15$ & $82 \pm 0.15$ \\
\hline & 2.5 & 2.5 & 2.00 & 2.00 & $80 \pm 0.12$ & $80 \pm 0.12$ \\
\hline & 5 & 5 & 4.25 & 4.15 & $85 \pm 0.11$ & $83 \pm 0.11$ \\
\hline
\end{tabular}

Table 1: Recoveries of 2,3,7,8 TCDD and 1, 2, 3, 7, 8 PCDD from spiked samples of milk (n=5)

\begin{tabular}{|c|c|c|c|c|}
\hline Concentration of $2,3,7,8$ TCDD (ppb) & Intra-day mean+SD (mv'S) & Precision (RSD\%) & Inter-day Mean+SD (mvS) & Precision (RSD \%) \\
\hline 0.75 & $734.73 \pm 10.81$ & 7.71 & $798.71 \pm 38.39$ & 7.19 \\
\hline 1.25 & $1602.42 \pm 43.25$ & 7.46 & $1679.40 \pm 43.36$ & 7.12 \\
\hline 2.5 & $3512.81 \pm 52.45$ & 5.12 & $3553.81 \pm 48.28$ & 4.74 \\
\hline 5 & $7376.77 \pm 95.98$ & 4.98 & $7429.72 \pm 93.23$ & 4.54 \\
\hline 10 & $14912.12 \pm 118.23$ & 3.6 & $15012.16 \pm 115.56$ & 2.88 \\
\hline
\end{tabular}

Table 2: Intra-day and inter-day RSD\% of 2,3,7,8 TCDD (precision).

\begin{tabular}{|c|c|c|c|c|}
\hline Concentration of $1,2,3,7,8 \mathrm{PCDD}(\mathrm{ppb})$ & Intra-day mean+SD (mv*S) & Precision (RSD\%) & Inter-day mean+SD (mv*S) & Precision (RSD\%) \\
\hline 0.75 & $863.31 \pm 34.23$ & 7.65 & $873.32 \pm 35.27$ & 7.46 \\
\hline 1.25 & $1692.59 \pm 42.12$ & 7.45 & $1728.54 \pm 43.26$ & 7.23 \\
\hline 2.5 & $3512.30 \pm 46.98$ & 4.67 & $3614.31 \pm 48.83$ & 4.34 \\
\hline 5 & $7052.35 \pm 92.87$ & 4.25 & $7154.18 \pm 93.34$ & 4.09 \\
\hline 10 & $14098.73 \pm 113.56$ & 2.67 & $14178.76 \pm 112.56$ & 2.45 \\
\hline
\end{tabular}

Table 3: Intra-day and inter-day RSD $\%$ of 1,2,3,7,8 PCDD (precision).

\begin{tabular}{|c|c|c|c|c|c|c|c|c|c|}
\hline \multirow[t]{3}{*}{ Company } & \multirow[t]{3}{*}{ season } & \multicolumn{2}{|c|}{ Mean } & \multicolumn{2}{|c|}{ Std. deviation } & \multicolumn{2}{|c|}{ Maximum } & \multicolumn{2}{|c|}{ Minimum } \\
\hline & & $2,3,7,8$ & $1,2,3,7,8$ & $2,3,7,8$ & $1,2,3,7,8$ & $2,3,7,8$ & $1,2,3,7,8$ & $2,3,7,8$ & $1,2,3,7,8$ \\
\hline & & TCDD & PCDD & TCDD & PCDD & TCDD & PCDD & TCDD & PCDD \\
\hline \multirow{4}{*}{ Pegah factory } & Summer & 3.12 & 2.81 & 0.13 & 0.06 & 3.17 & 2.87 & 3.09 & 2.76 \\
\hline & Autumn & 2.62 & 1.93 & 0.16 & 0.27 & 2.65 & 1.98 & 2.59 & 1.89 \\
\hline & Winter & 1.08 & 0.73 & 0.16 & 0.02 & 1.14 & 0.78 & 1.03 & 0.71 \\
\hline & Total & 2.27 & 1.82 & 1.13 & 1.04 & 3.17 & 2.87 & 1.03 & 0.71 \\
\hline \multirow{4}{*}{ Jamus factory } & Summer & 3.12 & 2.68 & 0.16 & 0.17 & 3.16 & 2.71 & 3.07 & 2.66 \\
\hline & Autumn & 2.59 & 1.8 & 0.49 & 0.06 & 2.67 & 1.85 & 2.5 & 1.78 \\
\hline & Winter & 1.01 & 0.72 & 0.04 & 0.02 & 1.06 & 0.77 & 0.96 & 0.69 \\
\hline & Total & 2.24 & 1.73 & 1.02 & 0.9 & 3.16 & 2.71 & 0.96 & 0.69 \\
\hline \multirow{4}{*}{ Torent factory } & Summer & 3.05 & 2.77 & 1.07 & 0.28 & 3.11 & 2.83 & 2.98 & 2.7 \\
\hline & Autumn & 2.61 & 1.89 & 0.12 & 0.69 & 2.63 & 1.92 & 2.59 & 1.86 \\
\hline & Winter & 1.15 & 0.63 & 0.15 & 0.04 & 1.17 & 0.69 & 1.1 & 0.59 \\
\hline & Total & 2.26 & 1.76 & 1.3 & 1.08 & 3.11 & 2.83 & 1.1 & 0.59 \\
\hline \multirow{4}{*}{ Total } & Summer & 3.09 & 2.75 & 0.89 & 0.16 & 3.17 & 2.87 & 2.98 & 2.66 \\
\hline & Autumn & 2.61 & 1.87 & 0.59 & 0.51 & 2.67 & 2.67 & 2.5 & 1.89 \\
\hline & Winter & 1.08 & 0.69 & 0.2 & 0.21 & 1.17 & 0.78 & 0.96 & 0.59 \\
\hline & Total & 2.25 & 1.77 & 1.1 & 0.99 & 3.17 & 2.87 & 0.96 & 0.59 \\
\hline \multicolumn{2}{|c|}{$\Sigma$ PCDFs-TEQ(pg/g fat) } & Summer & 5.84 & Autumn & 4.48 & Winter & 1.77 & Total & 4.02 \\
\hline
\end{tabular}

Table 4: The concentration of 2, 3, 7, 8 TCDD and 1, 2, 3, 7, 8 PCDD and TEQ concentration in investigated milk samples (ng/g fat).

results of present study and our concerns about the other potential sources and the consequence of bioaccumulation in human would fuel the more investigations.

\section{References}

1. Licata P, Trombetta D, Cristani M, Giofre F, Martino D, et al. (2004) Levels of "toxic" and "essential" metals in samples of bovine milk from various dairy farms in Calabria, Italy. Environ Int 30: 1-6.
2. Rappe C, Buser HR, Bosshardt HP (1979) Dioxins, dibenzofurans and other polyhalogenated aromatics: Production, use, formation, and destruction Annals of the New York Academy of Sciences 320: 1-18.

3. Poland A, Knutson JC (1982) 2, 3, 7, 8-Tetrachlorodibenzo-thorn-dioxin and related halogenated aromatic hydrocarbons: examination of the mechanism of toxicity. Annu Rev Pharmacol Toxicol 22: 517-554.

4. Kociba R, Keyes D, Beyer J, Carreon R, Wade C, et al. (1978) Results of a twoyear chronic toxicity and oncogenicity study of 2, 3, 7, 8-tetrachlorodibenzo-pdioxin in rats. Toxicol Appl Pharmacol 46: 279-303. 
Citation: Rezaei M, Khorasgani ZN, Nakisa A, Imani N, Rezaee S, et al. (2015) Determination of Polychlorinated Dibenzo Dioxin Levels in Fresh Milk from the Dairy Factories of Southwest Iran. J Environ Anal Toxicol 5: 301. doi:10.4172/2161-0525.1000301

5. Watanabe S, Kitamura K, Nagahashi M (1999) Effects of dioxins on human health: a review. J Epidemiol 9: 1-13.

6. McGregor DB, Partensky C, Wilbourn J, Rice JM (1998) An IARC evaluation of polychlorinated dibenzo-p-dioxins and polychlorinated dibenzofurans as risk factors in human carcinogenesis. Environ Health Perspect 106: 755

7. Charnley G, Doull J (2005) Human exposure to dioxins from food, 1999-2002. Food Chem Toxicol 43: 671-679.

8. Heilier J-F, Nackers F, Verougstraete V, Tonglet R, Lison D, et al. (2005) Increased dioxin-like compounds in the serum of women with peritoneal endometriosis and deep endometriotic (adenomyotic) nodules. Fertil Steril 84: 305-312.

9. Bovee TF, Hoogenboom LA, Hamers AR, Traag WA, Zuidema T, et al. (1998) Validation and use of the CALUX-bioassay for the determination of dioxins and PCBs in bovine milk. Food Addit Contam 15: 863-875.

10. Plomley JB, Lauševic M, March RE (2000) Determination of dioxins/furans and PCBs by quadrupole ion-trap gas chromatography-mass spectrometry. Mass Spectrom Rev 19: 305-365

11. Bandh C, Ishaq R, Broman D, Näf C, Rönquist-Nii Y, et al. (1995) Separation for subsequent analysis of PCBs, PCDD/Fs, and PAHs according to aromaticity and planarity using a two-dimensional HPLC system. Environ Sci Technol 30: 214-219.
12. Martinez-Cored M, Pujadas E, Diaz-Ferrero J, Coll M, Martí R, et al. (1999) Fractionation of polychlorinated dibenzo-p-dioxins, polychlorinated dibenzofurans and planar polychlorinated biphenyls by high performance liquid chromatography on a pyrenyl-silica column. Fresenius J Anal Chem 364: 576583

13. Kawashiro Y, Fukata H, Omori-Inoue M, Kubonoya K, Jotaki T, et al. (2008) Perinatal exposure to brominated flame retardants and polychlorinated biphenyls in Japan. Endocr J 55: 1071-1084.

14. Vartiainen T, Hallikainen A (1994) Polychlorodibenzo-p-dioxin and polychlorodibenzofuran levels in cow milk samples, egg samples and meat in Finland. Fresenius J Anal Chem 348: 150-153.

15. Ramos L, Eljarrat E, Hernandez L, Rivera J, Gonzalez M (1999) Levels of PCBs, PCDDs and PCDFs in commercial butter samples in Spain. Chemosphere 38: 3141-3153.

16. Focant JF, Eppe G, Pirard C, Massart AC, André JE, et al. (2002) Levels and congener distributions of PCDDs, PCDFs and non-ortho PCBs in Belgian foodstuffs--assessment of dietary intake. Chemosphere 48: 167-179.

17. Durand B, Dufour B, Fraisse D, Defour S, Duhem K, et al. (2008) Levels of PCDDs, PCDFs and dioxin-like PCBs in raw cow's milk collected in France in 2006. Chemosphere 70: 689-693.

18. Lizak R, Maszewski S, Piskorska-Pliszczyńska J (2009) Occurrence and profiles of polychlorinated dibenzo-p-dioxins, dibenzofurans, and dioxin-like polychlorinated biphenyls in polish farm milk. Bull Vet Inst Pulawy 53: 833-838. 